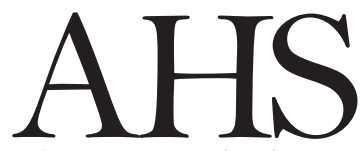

Advances in Horticultural Science
OPEN ACCESS

(*) Corresponding author:

bdamigou@gmail.com

Citation:

BAMMITE D., MATTHEWS P.J., DAGNON D.Y., AGBOGAN A., AGRE P., AKINTAYO T.O., ODAH K., DANSI A., ABBERTON M., TOZO K., 2021 - Genetic and morphological diversity in Colocasia esculenta and Xanthosoma maffafa in Togo, West Africa. - Adv. Hort. Sci., 35(3): 255-267

\section{Copyright:}

(C) 2021 Bammite D., Matthews P.J., Dagnon D.Y., Agbogan A., Agre P., Akintayo T.O., Odah K., Dansi A., Abberton M., Tozo K. This is an open access, peer reviewed article published by Firenze University Press

(http://www.fupress.net/index.php/ahs/) and distributed under the terms of the Creative Commons Attribution License, which permits unrestricted use, distribution, and reproduction in any medium, provided the original author and source are credited.

Data Availability Statement:

All relevant data are within the paper and its Supporting Information files.

Competing Interests:

The authors declare no competing interests.

Received for publication 9 September 2020 Accepted for publication 9 July 2021

\title{
Genetic diversity in Colocasia esculenta and Xanthosoma mafaffa in Togo, West Africa
}

\author{
D. Bammite ${ }^{1(*)}$, P.J. Matthews ${ }^{2}$, D.Y. Dagnon ${ }^{1}$, A. Agbogan ${ }^{1}$, P. Agre ${ }^{3}$, \\ T.O. Akintayo ${ }^{3}$, K. Odah ${ }^{1}$, A. Dansi ${ }^{4}$, M. Abberton ${ }^{3}$, K. Tozo ${ }^{1}$ \\ 1 Laboratoire de Physiologie et Biotechnologie Végétale, Faculté des \\ Sciences, Université de Lomé, Boulevard Gnassingbé Eyadema, \\ 01BP1515 Lomé, Togo. \\ 2 National Museum of Ethnology, Senri Expo Park 10-1, Osaka 565-8511, \\ Japan. \\ 3 International Institute of Tropical Agriculture (IITA), Bioscience Center, \\ PMB 5320, Oyo Road, Ibadan, Nigeria. \\ 4 Université Polytechnique d'Abomey, Faculté des Sciences et Techniques \\ de Dassa, Laboratoire de Biotechnique, Ressources Génétiques et \\ Amélioration des Espèces Animales et Végétales (BIORAVE), Bénin.
}

Key words: crop diversity, new cocoyam, SSR, taro, Togo.

Abstract: Taro and new cocoyam are root and leaf crops commonly grown in tropical to warm temperate regions. In Togo, they are neglected and underutilized. Here we report the genetic diversity of 26 accessions of taro and 101 accessions of new cocoyam. Analysis of simple sequence repeats revealed low polymorphic information content of 0.43 and 0.25 in taro and new cocoyam, respectively. PCA scatterplots and Neighbour Joining dendrograms based on the SSR data clustered accessions into groups that more-or-less correspond to morphological diversity in both species. AMOVA within and between morphological groups revealed greater variances within groups than between. This indicates weak genetic differentiation between morphological groups, particularly for taro. Genetic diversity was greater among taro cultivars. Taro has a longer history of introduction and dispersal in Africa, and has had more opportunity for multiple introduction and local cultivar development. Different strategies are suggested for future development of these crops in Togo and Africa. For taro, further studies of existing diversity and recent experimental introductions to Africa are likely to be rewarding. New cocoyam, a modern historical introduction, has spread widely in Africa with little genetic diversity. For this crop, international collaboration is needed to clarify taxonomy, and to introduce further cultivars for evaluation under local conditions in Africa.

\section{Introduction}

Root and tuber crops are important sources of food and income for household in rural areas of Africa. In sub-Saharan Africa, they provide 
about $20 \%$ of calories (Pinstrup-Andersen et al., 1999). Taro, Colocasia esculenta (L.) Schott and new cocoyam, Xanthosoma spp., are grown for food and income generation at the household level. Both crops are grown in tropical regions of Africa, Asia, Oceania and America, and taro is also common in temperate regions of Africa, Asia, and Oceania (Gonçalves, 2011; Matthews, 2014; Onyeka, 2014; Grimaldi, 2016; Matthews and Ghanem, 2021). Taro is considered an ancient crop in Africa, with multiple likely routes of introduction from Asia (Matthews, 2006; Fuller et al., 2011; Chaïr et al., 2016; Grimaldi, 2016). New cocoyam is known to have been introduced to Ghana in 1843 (Karikari, 1971), though earlier introduction following European contact with America has been suggested (Bown, 2000).

Most parts of these plants (corms, side-corms, stolons, petioles, leaf blades, and floral spathes) are edible, the leaves and corms are also commonly used as animal fodder in Asia (Coursey, 1984; Matthews, 2010; Mwenye et al., 2010; Masuno et al., 2012; Matthews, 2014; Wada et al., 2017), and medicinal uses are also known (Plowman, 1969; Ribeiro Pereira et al., 2021). The specific parts eaten vary according to cultivar attributes, local food knowledge, and cultural or personal preferences. Both crops have great potential for development in Africa and globally (Okereke, 2020).

Under cultivation, clonal propagation is universal for both taro and new cocoyam. In a global survey of taro, Chaïr et al. (2016) found the greatest genetic diversity and the largest number of private alleles in Asian cultivars, especially in India. Low genetic diversity was found in western Africa, among diploid and triploid cultivars, and also in southern Africa, where triploid cultivars were dominant. Their observations correspond broadly to what is known about the breeding of taro: flowering, fruiting and seed production by wild and cultivated taros are common in tropical regions of Asia and Oceania (Matthews, 2014), but have not been observed in Africa despite occasional reports of flowering (e.g. Traore, 2013). Natural fruiting and seed production by new cocoyam has not been reported outside South America, but sterile inflorescences are often produced (observation by authors), and induced flowering and experimental crosses have been reported in Cameroon (Onokpise et al., 1992).

Globally, taro has undergone genetic erosion due to changes in cropping patterns, the spread of improved varieties, and replacement by other crops (Lakhanpaul et al., 2003; Matthews and Ghanem,
2021), including new cocoyam (Coursey, 1984). The acridity of taro (and resulting special care needed for cooking) (Matthews, 2010), spread of taro leaf blight (TLB) (Singh et al., 2012), and shortages of planting materials are contributing factors. In order to identify and preserve cultivars of economic value, maintain living germplasm collections efficiently (without excessive duplication), and provide baseline data for future breeding programs, genetic diversity and morphology must be assessed in cultivars of both species.

The taxonomy of cultivated Xanthosoma species and relationships with wild species are uncertain, and historically there has been a tendency to use the name $X$. sagittifolium for all cultivated Xanthosoma (Giacometti and Leon, 1994; Castro, 2006; QueroGarcia et al., 2010; Doungous et al., 2015). Although $X$. sagittifolium is the name used in many previous studies in Africa, the plant is most likely to be $X$. mafaffa (Gonçalves, 2011). The taxonomy of cultivated Xanthosoma spp. in tropical America has been revised by Croat and Delannay (2017). Various cultivated species of Xanthosoma are also circulating internationally and may have reached Africa in the modern historical period. These include $X$. atrovirens C. Koch \& Bouché (blackish green blades, and "blue" wax on dark green petioles creating a dark purple or black appearance), $X$. robustum (which can reach $4 \mathrm{~m}$ in height, with tall above-ground stems) and $X$. violaceum (with violet petiole tissue below a waxy surface) (Gonçalves, 2011). In addition to the 1843 introduction of Xanthosoma (Karikari, 1971), an unsuccessful attempt was made to introduce $X$. brasiliensis from Puerto Rico in 1974 (Karikari, 1979). In Central America, X. mafaffa cultivars vary in corm parenchyma color (red or white), and those with red corms are also tinged with red in the petiole, leaf sheath and spathe (Gonçalves, 2011).

In Togo, a collection of taro and new cocoyam cultivars from throughout the country was assembled, and morphological groups were described in both species (Bammite, 2018; Bammite et al., 2018 a, b). However, data related to genetic diversity among these crops, based on molecular tools such as SSR, are lacking to enhance effective usage and conservation of these neglected species and develop a breeding program to improve the quality of their germplasm. This study aimed to assess simple sequence repeat (SSR) diversity in the same collection of taro and new cocoyam. Polymorphic SSR loci have codominant alleles (repeat sequences of varying length, detected by PCR amplification), and been 
used in many studies of taro (Devi, 2012; You et al., 2015) and other edible aroids (Suppl. Table S1), and in genetic linkage mapping of the taro nuclear genome (Quero-García et al., 2010; Soulard et al., 2017).

\section{Materials and Methods}

\section{Plant materials}

In 2016, cultivars of taro and new cocoyam were collected from 42 localities randomly selected across the five ecological zones of Togo (Fig. 1). At each village, farmers were invited to bring corms of different cultivars grown in their village. For each distinct cultivar recongnized in group discussions, the local name was recorded and collected corm samples were planted at the Centre de Recherche Agronomique du Litoral (CRAL), an experimental farm of the Institut

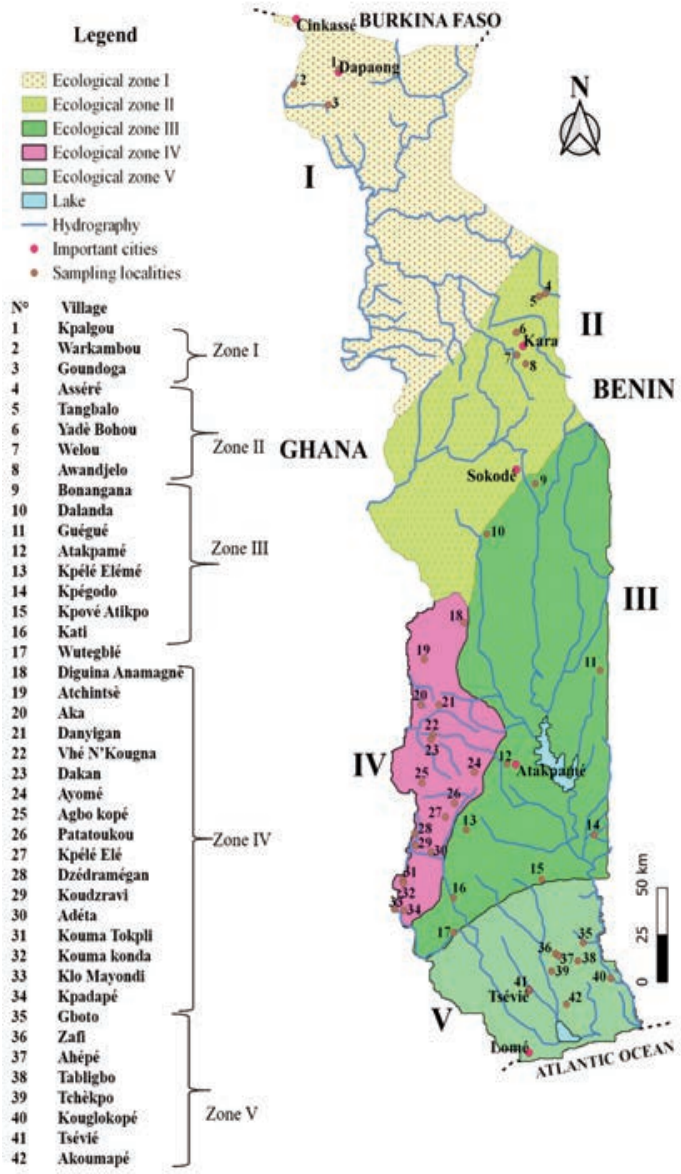

Fig. 1 - Map of Togo showing sampling localities in 2016 and ecological zones: Zone I, Northern lowlands; Zone II, Northern Togo mountains; Zone III, Central lowlands; Zone IV, Southern Togo mountains; Zone V, Coastal plains of southern Togo. Figure adopted from Bammite et al., 2018 b; zones originally described by Ern (1979); base map from IGN France, 1990.
Togolais de Recherche Agronomique (ITRA) located at Davié, at latitude N $6^{\circ} 23^{\prime}$ and longitude E $1^{\circ} 12^{\prime}$ and at $88 \mathrm{~m}$ above sea level (Table S2). Accessions of both species were classified in a binary manner based on morphological characters that are easily observed in the field: taro accessions were identified as either dasheen (with large mother corms, and either stolons or side-corms; Pop1), or eddoe (with small mother corms, and few to many side-corms; Pop2); new cocoyam accessions were identified as either green (leaves entirely green; Pop1) or purple (petioles purple or pink to some extent; Pop2). Morpological diversity in the same collection was previously analysed with reference to a wide range of agronomic and morphological characters (Bammite et al., 2018 b; Figs. S1-S3). Young leaf tissue from one plant from each of 26 accessions of taro and 101 accessions of new cocoyam was dried on silica gel and taken to the International Institute of Tropical Agriculture (IITA) Bioscience Centre, Ibadan, Nigeria for DNA extraction and genotyping.

\section{DNA isolation and quantification}

DNA was extracted using an optimized SDS protocol recommended by IITA Bioscience Centre (2017). About $100 \mathrm{mg}$ of dry leaf tissue was put in a tube with two steel balls and reduced to powder using a SPEX Genogrinder-2000. Pre-heated extraction buffer (450 $\mu$ l of $1 \mathrm{M}$ Tris- $\mathrm{HCl}, 0,5 \mathrm{M}$ EDTA, $5 \mathrm{M} \mathrm{NaCl}, 20 \%$ SDS and $1 \%$ PVP) was added. Tubes were incubated at $65^{\circ} \mathrm{C}$ for 20 mins and inverted occasionally to homogenize each sample. Tubes were removed from bath, allowed to cool for two mins, then $200 \mu$ l of ice-cold $5 \mathrm{M}$ potassium acetate was added and the mixture incubated on ice for 20 mins to precipitate proteins. Tubes were then centrifuged at $3500 \mathrm{rpm}$ for 10 mins, and each supernatant was transferred to a new labeled tube. A volume of $200 \mu \mathrm{l}$ of $4 \%$ polyvinylpyrrolidone (PVP) was added to the supernatant and gently mixed. To precipitate and remove proteins and lipids, $45 \mu \mathrm{l}$ of chloroform isoamylalchohol (24:1) was added, mixed gently and tubes were centrifuged at $3500 \mathrm{rpm}$ for 15 mins. Each supernatant was transferred to a new tube, and a $2 / 3$ volume of ice-cold isopropanol was added, mixed, and incubated in $-80^{\circ} \mathrm{C}$ for 15 mins to precipitate the DNA. After centrifuging at $3500 \mathrm{rpm}$ for 15 mins, the DNA pellet was washed by adding $400 \mu \mathrm{l}$ of $70 \%$ ethanol, centrifugation at $3500 \mathrm{rpm}$ for 15 mins, and decanting the supernatant until the last drop. The DNA pellet was air-dried then resuspended in $100 \mu$ l low salt TE buffer (10 mM Tris- $\mathrm{HCl}, 1 \mathrm{mM}$ 
EDTA). A volume of $2 \mu \mathrm{l}$ of RNase A (10 $\mu \mathrm{g} / \mathrm{ml})$ was added and incubated at $37^{\circ} \mathrm{C}$ for 40 mins. The quantity and quality of extracted DNA was checked using electrophoresis with $1 \%$ agarose gel, and a Nanodrop 8000 spectrophotometer, and the extracts were stored at $-20^{\circ} \mathrm{C}$ until use.

\section{PCR amplification}

Initial testing was carried out with 47 primer pairs designed in previous SSR studies: 19 for for Amorphophallus paeoniifolius (Santosa et al., 2007), 11 for C. esculenta (Hu et al., 2009.) and 17 for $X$. sagittifolium (Cathebras et al., 2014) (Table S3). The 47 primer pairs were tested first with five samples from each target species to determine which pairs could amplify scorable DNA products in each species.

PCR amplification was performed in PCR mixture $(25 \mu \mathrm{l})$ containing $2.5 \mu \mathrm{l}$ of template DNA $(20 \mathrm{ng} / \mu \mathrm{l})$, $2.5 \mu \mathrm{l}$ of $10 \mathrm{x}$ NH4 PCR reaction buffer, $1 \mu \mathrm{l}$ of $50 \mathrm{mM}$ $\left.\mathrm{MgCl}_{2}\right), 1 \mu \mathrm{l}$ of $5 \mu \mathrm{M}$ forward primer, $1 \mu$ of $5 \mu \mathrm{M}$ reverse primer, $0.2 \mu \mathrm{l}$ of $5 \mathrm{mM}$ each dNTP, $0.1 \mu \mathrm{l}$ of BIOTAQ DNA polymerase and $16.1 \mu \mathrm{l}$ of water. The PCR program consisted of initial denaturation $\left(94^{\circ} \mathrm{C}\right.$, 5 mins), 42 cycles each consisting of $20 \mathrm{~s}$ denaturation $\left(93^{\circ} \mathrm{C}\right), 1 \mathrm{~min}$ annealing at temperatures ranging from 47 to $59^{\circ} \mathrm{C}$ (as recommended by the authors above; Table S3), and 2 mins elongation $\left(72^{\circ} \mathrm{C}\right)$. Finally, an extension period of 10 mins was included. After PCR completion, the products were stored at $4^{\circ} \mathrm{C}$ until gel electrophoresis. Ten $\mu$ of each PCR product was electrophoresed alongside a 50 bp DNA ladder (New England Biolab) in polyacrylamide gel (10\% InstaPAGE gel) at $110 \mathrm{~V}$ for one hour, and bands were visualized by silver staining (1L TBE $0,5 X$ buffer $+500 \mu \mathrm{L}$ of SafeView) for 3 mins. Amplified fragment sizes were determined by comparison to the $50 \mathrm{bp}$ ladder, and bands were examined and recorded using the ENDURO ${ }^{\mathrm{TM}}$ Gel Documentation System.

\section{Data analysis}

Recorded gel images with PCR products were analysed the the Image Studio Lite Ver 5.2 software, generating binary matrix data for all accessions based on the band patterns observed at each SSR locus: presence of an amplified band was scored as " 1 "; absence was scored as " 0 ". Summary statistics for each locus were estimated using PowerMarker 3.25 software.

For statistical comparisons within each species, the binary classifications of morphotypes were used: taro dasheen $=$ Pop 1, eddoe $=$ Pop2; new cocoyam - green $=$ Pop1, purple $=$ Pop2. GenAlex 6.5 software (Peakall and Smouse, 2006) was used to calculate the number of polymorphic loci (no. PL), the percentage of polymorphic loci (\% PL), the observed number of alleles $(\mathrm{Na})$, the effective number of alleles ( $\mathrm{Ne})$, average expected heterozygosity (He) (also known as Nei's gene diversity, Nei, 1973), and Shannon's information index (I) (a measure of genetic diversity suitable for codominant data). Analysis of molecular variance (AMOVA) was performed to evaluate the genetic variation within and among morphotype populations by using GenAlEx version 6.503 (Peakall and Smouse, 2006), and PhiPT (the proportion of total genetic variance derived from variance between individuals among populations, i.e. an estimate of population genetic differentiation). Here, our $H_{0}=$ no genetic difference among populations, $H_{1}=$ there is genetic difference among populations, and $p=$ probability of an observed PHiPT value $=/>$ than that observed by chance, if the null hypothesis (no genetic difference) is true.

Principal Coordinate Analysis (PCA) was carried out using the GenAlEx version 6.503 (Peakall and Smouse, 2006). The genetic distance matrix was constructed by calculating the shared allele distance for each pair of individuals in PowerMarker version 3.25. From this matrix, a neighbour joining (NJ) tree was constructed using Nei's genetic distances (Nei et al., 1983 ) in the same software.

\section{Results}

In the initial test with five samples of each target species, only 27 of 47 SSR primer pairs, amplified and gave polymorphic, scorable bands (Fig. 2; Table S3):

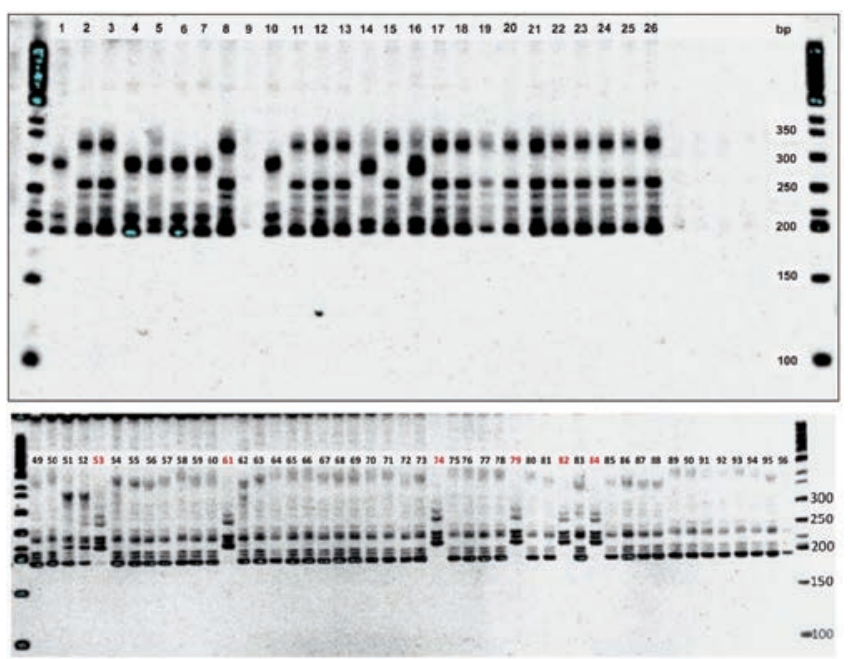

Fig. 2 - Electrophoresis of PCR amplification products to show SSR polymorphism. Above: taro tested with primer pair HK29; empty lanes at right are null results for new cocoyam tested with HK29. Below: new cocoyam tested with primer pair $\mathrm{mXsCIR} 10$. 
two from Amorphophallus amplified both target species, 11 from $C$. esculenta amplified only C. esculenta and 14 from $X$. sagittifolium amplified only $X$. mafaffa. The resulting measures of diversity for each species are shown in Tables 1 and 4, and are summarised below.

Among 26 accessions of taro, 33 alleles were observed at 13 loci, an average of 3.15 alleles per locus (loci are hereafter identified by the primer code names). The frequency of major alleles ranged from 0.38 for locus HK7 to 0.88 for HK5, with an average of 0.62. Nei's gene diversity ranged from 0.21 for HK7 to 0.71 for HK5, with an average of 0.49 . Polymorphic information content (PIC) values ranged from 0.20 to 0.65 with an average of 0.43 . The primers HK35, HK26, HK38, Ampa9, HK7 with PIC values $>/=0.5$ were most discriminating (Table 1). The percentages of polymorphic loci for each morphotype of taro were $82 \%$ (dasheen, Pop1) and 58\% (eddoe, Pop2), with an average of $70 \%$ (rounded figures). The numbers of different ( $\mathrm{Na}$ ) and effective ( $\mathrm{Ne}$ ) alleles, Shanons Information Index (I), and Nei's gene diversity $(\mathrm{He})$ were all higher in dasheen and lower in eddoe (Table 2).

Table 1 - Taro: Frequency of major alleles, number of alleles, Nei's genetic diversity, and polymorphism information content (PIC) for 13 primers applied to 26 accessions (Togo collection)

\begin{tabular}{lcccc}
\hline Locus & Freq. major alleles & No. alleles & Genetic diversity & \\
HK5 & 0.88 & 3 & 0.21 & 0.2 \\
Ampa15 & 0.85 & 3 & 0.27 & 0.26 \\
HK25 & 0.77 & 2 & 0.36 & 0.29 \\
HK31 & 0.65 & 2 & 0.45 & 0.35 \\
HK29 & 0.65 & 3 & 0.48 & 0.39 \\
AC3 & 0.5 & 3 & 0.54 & 0.43 \\
HK22 & 0.65 & 3 & 0.51 & 0.45 \\
HK34 & 0.65 & 3 & 0.51 & 0.45 \\
HK35 & 0.65 & 4 & 0.52 & 0.48 \\
HK26 & 0.54 & 3 & 0.59 & 0.52 \\
HK38 & 0.42 & 3 & 0.64 & 0.56 \\
Ampa9 & 0.42 & 5 & 0.66 & 0.59 \\
HK7 & 0.38 & 4 & 0.71 & 0.45 \\
Mean & 0.62 & 3.15 & 0.49 & \\
\hline
\end{tabular}

Table 2A - Taro: Statistical measures of genetic diversity in the dasheen and eddoe populations (Togo collection)

\begin{tabular}{lcccccc}
\hline & $N$ & $N a$ & Ne & I & He & \\
& & & & 0.451 & 0.307 & \\
\hline Pop1 (dasheen) & 15 & 1.758 & 1.546 & 0.251 & 0.156 & 58 \\
Pop2 (eddoe) & 11 & 1.364 & 1.234 & 0.351 & 0.231 & 70 \\
Mean & & 1.561 & 1.39 & 0.033 & 0.024 & 12 \\
SE & & 0.089 & 0.045 & & \\
\hline
\end{tabular}

$\mathrm{N}=$ no. accessions (test population), $\mathrm{Na}=$ no. of different alleles, $\mathrm{Ne}=$ no. of effective alleles, I = Shannon's Information Index, He = Nei's gene diversity, $\% \mathrm{P}=$ percentage of polymorphic loci (rounded figures)

Table 2B - Taro: Summary analysis of molecular variation (AMOVA) in the dasheen and eddoe populations (Togo collection)

\begin{tabular}{lccccccc}
\hline & $\mathrm{df}$ & $\mathrm{SS}$ & $\mathrm{MS}$ & Est. var. & \% var. & PhiPT & p value \\
\hline Between pops & 1 & 15.962 & 15.962 & 0.915 & $17 \%$ & 0.174 \\
Within pops & 24 & 104.23 & 4.343 & 4.343 & $83 \%$ & 0.014 \\
Total & 25 & 120.192 & - & 5.258 & $100 \%$ & \\
\hline
\end{tabular}

$\mathrm{df}=$ degrees of freedom, $\mathrm{SS}=$ sum of squares, MS = mean sum of squares, Est. var. = estimated variance, \% var = percentage of variation, PhiPT = proportion of total genetic variance derived from variance between individuals among populations, $p=$ probability value for PhiPT. 
Among the 101 accessions of new cocoyam, 48 alleles were observed at 16 loci, an average of 3.0 alleles per locus. The frequency of major alleles ranged from 0.47 for Ampa9 to 0.97 for Ampa15, with an average of 0.83 . Nei's gene diversity $(\mathrm{He})$ ranged from 0.06 for Ampa9 to 0.67 for Ampa15, with an average of 0.28 . PIC values ranged from 0.06 to 0.62 , with an average of 0.25 . Only the Ampa9 locus gave a PIC value greater than 0.5 (Table 3 ).

The percentages of polymorphic loci for each morphotype of new cocoyam were $74 \%$ (green, Pop1) and 94\% (purple, Pop2) and with an average of $84 \%$ (rounded figures). A lower number of different alleles was recorded in the green population ( $\mathrm{Na}=$ $1.74, n=23$ ) and a higher number in the purple population ( $\mathrm{Na}=1.87, \mathrm{n}=78$ ), but the number of effective alleles $(\mathrm{Ne})$ and other measures of diversity ( $\mathrm{I}$, $\mathrm{He}$ ) were higher in the green population (Table 4).

\section{Cluster analysis and structuring of genetic diversity}

Analysis of molecular variance (AMOVA) gave percentages of molecular variance of $83 \%$ within and $17 \%$ between the dasheen and eddoe populations of taro, indicating weak differentiation overall (Table 2). For new cocoyam, the percentages of molecular variance were $64 \%$ within and $36 \%$ between the green and purple population (Table 4). The probability value $(p)$ for PhiPT is higher in taro $(0.014)$ than in new cocoyam (0.001) providing for taro a weaker rejection of the $H_{0}$ of no genetic difference between
Table 3 - New cocoyam: Frequency of major alleles, number of alleles, Nei's genetic diversity, and polymorphism information content (PIC) for 16 primers applied to 101 accessions (Togo collection)

\begin{tabular}{clcccc}
\hline$\#$ & Locus & $\begin{array}{c}\text { Freq. major } \\
\text { alleles }\end{array}$ & $\begin{array}{c}\text { No. of } \\
\text { alleles }\end{array}$ & $\begin{array}{c}\text { Genetic } \\
\text { Diversity }\end{array}$ & PIC \\
\hline 1 & Ampa15 & 0.97 & 3 & 0.06 & 0.06 \\
2 & $m X s C I R 1$ & 0.95 & 2 & 0.09 & 0.09 \\
3 & $m X s C I R 1$ & 0.94 & 2 & 0.11 & 0.11 \\
4 & $m X s C I R 0$ & 0.89 & 2 & 0.19 & 0.18 \\
5 & $m X s C I R 1$ & 0.87 & 3 & 0.23 & 0.21 \\
6 & $m X s C I R 1$ & 0.87 & 3 & 0.23 & 0.21 \\
7 & $m X s C I R 1$ & 0.85 & 3 & 0.26 & 0.23 \\
8 & $m X s C I R 2$ & 0.86 & 3 & 0.25 & 0.23 \\
9 & $m X s C I R 2$ & 0.85 & 3 & 0.26 & 0.23 \\
10 & $m X s C I R 2$ & 0.84 & 3 & 0.27 & 0.24 \\
11 & $m X s C I R 1$ & 0.83 & 3 & 0.29 & 0.27 \\
12 & $m X s C I R 2$ & 0.79 & 3 & 0.35 & 0.32 \\
13 & $m X s C I R 0$ & 0.76 & 4 & 0.39 & 0.35 \\
14 & $m X s C I R 2$ & 0.77 & 4 & 0.38 & 0.35 \\
15 & $m X s C I R 1$ & 0.76 & 3 & 0.39 & 0.35 \\
16 & Ampa9 & 0.47 & 4 & 0.67 & 0.62 \\
Means & & 0.83 & 3 & 0.28 & 0.25 \\
\hline
\end{tabular}

populations.

The first and second coordinates of the PCA scatter plot (Fig. 3) represent, respectively, $48 \%$ and $16 \%$ (in total 64\%; rounded figures) of the detected variability among taro accessions. For cocoyam accessions, the coordinates represented $41 \%$ and $13 \%$ (in total $54 \%$ ) (Fig. 4). Some dasheen taros formed a distinct group along the first coordinate, but apart from

Table 4A - New cocoyam: Statistical measures of genetic diversity in the green and purple populations (Togo collection)

\begin{tabular}{lcccccc}
\hline & $\mathrm{N}$ & $\mathrm{Na}$ & $\mathrm{Ne}$ & $\mathrm{I}$ & $\mathrm{He}$ & $\% \mathrm{P}$ \\
\hline Pop1 (green) & 23 & 1.742 & 1.532 & 0.418 & 0.287 & 74 \\
Pop2 (purple) & 78 & 1.871 & 1.176 & 0.23 & 0.128 & 94 \\
Mean & & 1.806 & 1.354 & 0.324 & 0.208 & 84 \\
SE & & 0.06 & 0.05 & 0.033 & 0.024 & 10 \\
\hline
\end{tabular}

$\mathrm{N}=$ no. accessions tested, $\mathrm{Na}=$ average no. of alleles observed per locus, $\mathrm{Ne}=$ no. of effective alleles, I = Shannon's Information Index, He $=$ Nei's gene diversity, \% $\mathrm{P}=$ percentage of polymorphic loci (rounded figures).

Table 4B - New cocoyam: Summary analysis of molecular variation (AMOVA) in the green and purple populations (Togo collection)

\begin{tabular}{lccccccc}
\hline Source & $\mathrm{df}$ & $\mathrm{SS}$ & $\mathrm{MS}$ & Est. var. & $\%$ var. & PhiPT & $\mathrm{p}$ value \\
\hline Between pops & 1 & 54.566 & 54.566 & 1.463 & $36 \%$ & 0.36 & 0.001 \\
Within pops & 99 & 257.255 & 2.599 & 2.599 & $64 \%$ & & \\
Total & 100 & 311.822 & - & 4.061 & $100 \%$ & \\
\hline
\end{tabular}

$\mathrm{df}=$ degrees of freedom, $\mathrm{SS}$ = sum of squares, MS = mean sum of squares, Est. var. = estimated variance, \% var = percentage of variation, PhiPT = proportion of total genetic variance derived from variance between individuals among populations, $p=$ probability value for PhiPT. 


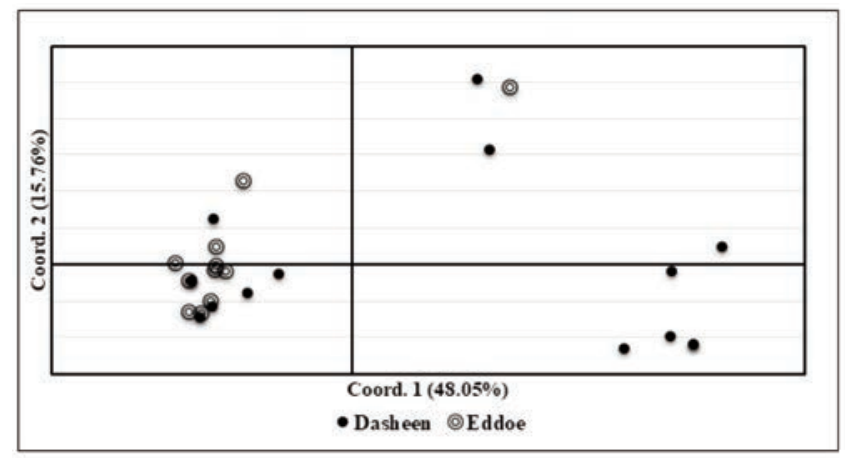

Fig. 3 - Principal coordinate analysis (PCA) of Taro accessions classified as dasheen or eddoe.

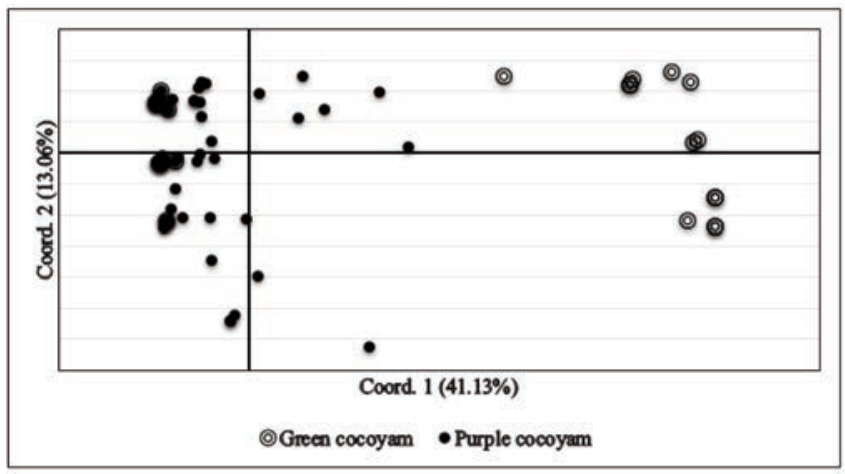

Fig. 4 - Principal coordinate analysis (PCA) of new cocoyam accessions classified as green or purple.

this, there is no clear separation of dasheen and eddoe accessions overall in the SSR data. In contrast, the green and purple new cocoyam formed very distinct groups along the first PCA coordinate. These relationships between SSR diversity in PCA scatterplot and simple morphotype classification are mirrored in the NJ dendrograms.

The NJ dendrogram of SSR diversity in taro (Fig. 5) revealed one larger cluster (C1) that includes a mix of dasheen (7 accessions) and eddoe types (10 accessions), and a two clusters (C2, C3) that include dasheen types only (9 accessions). The accessions in C3 were all dasheen types, from wet, flooded environments, with purple petiole and petiole junction, and generally producing many stolons (see Discussion and Conclusions) (Fig. S1A, Fig. S2).

The NJ dendrogram of SSR diversity in new cocoyam revealed two large clusters (C1 and C2) (Fig. 6) that largely correspond to the green and purple morphotypes of this species (13 and 88 accessions in each category; and many identical haplotypes).

With regard to the more specific morphological groups previously reported, C1 includes mostly G1, and $\mathrm{C} 2$ includes a mix of mostly $\mathrm{G} 2$ and $\mathrm{G} 3$ (purple morphotypes; Fig. S3).

\section{Discussion and Conclusions}

The present SSR results indicate few duplicate accessions in the smaller collection of taro (Fig. 5) and many apparent duplicates in the larger collection of $X$. mafaffa (Fig. 6). Qualitative and quantitative traits for morphological and agronomic characters of taro and new cocoyam were previously recorded and analysed by Bammite et al. (2018 b). Thirty-eight characters were selected from the descriptor list of IPGRI (1999) for C. esculenta and 28 from the descriptor list of IBPGR (1989) for X. saggitifolium. Based on these detailed observations, morphological groups within each species were identified using UPGMA analysis (Fig. S1). Although these groups (G1-

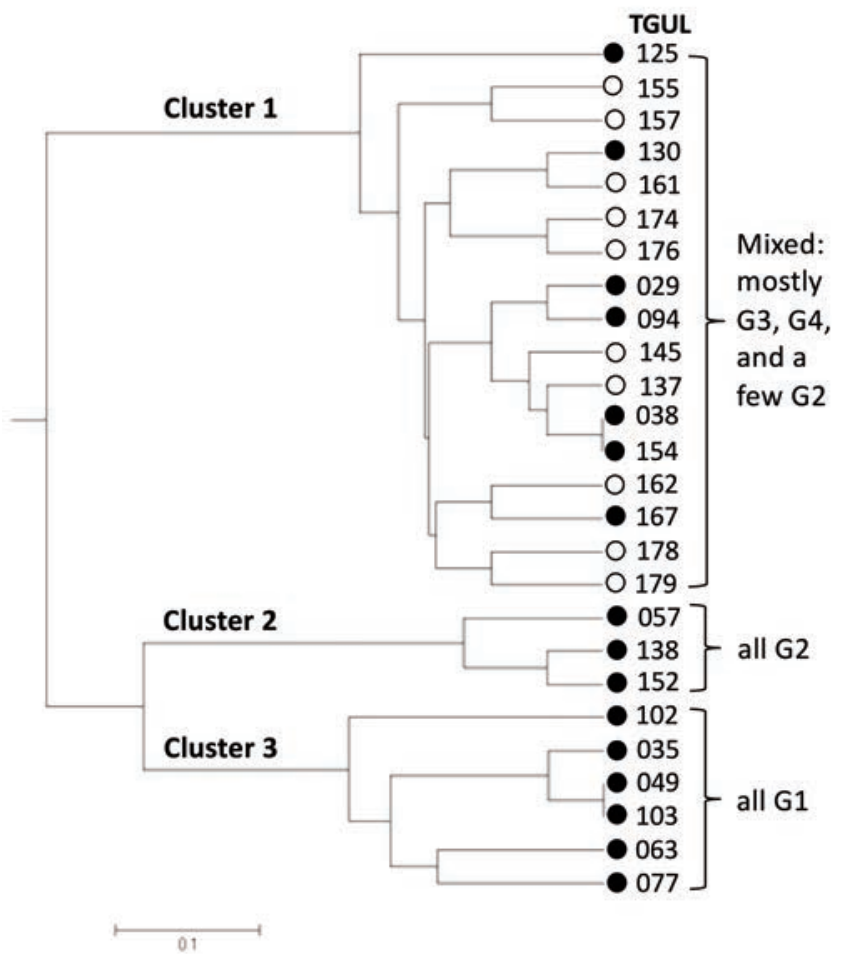

Fig. 5 - Taro: Neighbour Joining tree based on SSR data from 13 loci in 26 accessions. Cluster 1 includes both dasheen (closed circles) and eddoe (open circles) morphotypes. Clusters 2 and 3 include only dasheen morphotypes. Morphological groups identified by Bammite et al. (2018 b) (Figs. S1A and S2) are mixed in Cluster 1 (mostly G3, G4 and a few G2) and not mixed in Clusters 2 and 3. TGUL (Togo, University of Lomé) accession numbers are shown. 


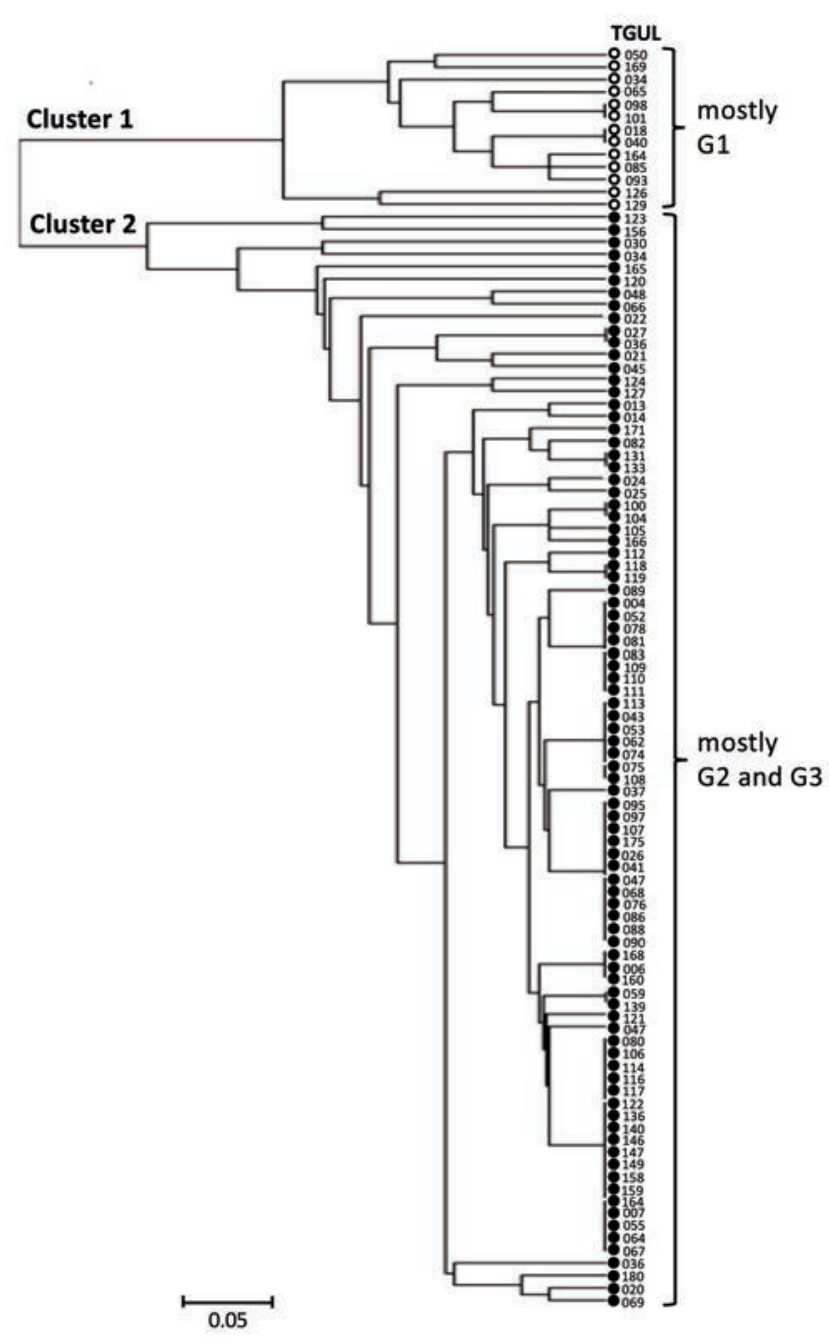

Fig. 6 - New cocoyam: Neighbour Joining tree based on SSR data from 16 loci in 101 accessions collected in Togo. Cluster 1 includes green morphotypes (open circles) and Cluster 2 includes purple morphotypes (closed circles). Morphological groups identified by Bammite et al. (2018b) (Figs. S1B and S3) are slightly mixed in both clusters (a few G2 and G3 in Cluster 1, and a few G1 in Cluster 2). TGUL (Togo, University of Lomé) accession numbers are shown.

G4 in taro, G1-G3 in new cocoyam) do not always correspond as expected to the single-character categories used in the present study (corm size and shape in taro, plant colour in new cocoyam) (Figs. S2 and S3), congruences are apparent between SSR genetic diversity and morphological diversity, however the latter is defined. Complete correspondence between single-character and multi-character classifications is not expected, but future studies of morphological diversity can be improved by ensuring greater uniformity in the planting materials used.

Ahmed et al. (2020) found that the dasheen/ eddoe classification corresponds to two distinct evolutionary lineages within C. esculenta, and suggested that the existence of many intermediate or mixed morphotypes may reflect hybridisation between these lineages. In Togo, SSR cluster C1 includes both dasheen and eddoe forms, consistent with the suggestion of mixing (hybridisation) between eddoe and dasheen lineages (see also Lakhanpaul et al., 2003). Clusters C2 and C3 corresponded entirely to dasheen forms with large mother corms and either stolons or side-corms. The three accessions in C2 had morphological above-ground traits similar to those typical of eddoe in the Togo collection (large pendant or drooping leaves) and underground morphological traits of dasheen type (G2, with large central corm with small side-corms). These accessions were collected in home gardens of farmers from Kabyè ethnic group in the ecologic zone IV (southern Togo Mountains) (Fig. 1). They reported having introduced them from ecological zone II (northern Togo Mountains), which is consistent with the report by Ern (1979) of an expansion of banana, cassava and taro production on steep slopes in Zone IV by Kabyè settlers from the north.

The observation of two major SSR clusters in new cocoyam (C1-C2) suggests that more than one species of Xanthosoma is present in Togo, not just $X$. mafaffa (Bammite et al., 2018 a, b). A survey of Amplified Fragment Length Polymorphism (AFLP) in new cocoyam in Ethiopia also revealed two major clusters (Wada et al., 2018). The existence of such distinct lineages and the general uncertainty of identification of Xanthosoma species suggest an urgent need for direct and detailed comparisons between cultivated Xanthosoma spp. in Africa, and the wild and cultivated species of Xanthosoma in tropical America.

For both species, the Neighbour Joining analysis of SSR allelic diversity at a small number of loci provides tree diagrams in which terminal branching (near tree tips) is not a reliable indicator of phylogeny. Much of the "within population" variation in both species may reflect somatic mutation within clonal cultivar lineages. The small numbers of loci analysed here (13 in taro, 14 in new cocoyam) make it inherently difficult to distinguish clones with certainty, as there are 14 chromosomes in the haploid complement of $C$. esculenta (Coates et al., 1988; Cusimano et al., 2012), and 13 in Xanthosoma spp. (Cusimano et al., 2012; Wada et al., 2018) giving rounded averages of just 0.9 loci (taro) and 1.1 loci (new cocoyam) 
sampled per chromosome. For taro, actual coverage is less than 0.9 loci/chromosome, as two HK loci have been mapped to one linkage group and chromosome (Table S4). Although Chaïr et al. (2016) introduced a method to estimate clonality based on just 11 loci, the same research group also employed a much more robust method using Diversity Array Technology (DArT ${ }^{\mathrm{TM}}$ ) to screen polymorphic loci (possibly thousands) across the entire taro genome (Vandenbrouke et al., 2016). By combining the latter method with a detailed survey of morphological diversity in an assemblage of Vanuatu cultivars, Vandenbrouke et al. (2016) could unequivocally identify clonal lineages within which somatic mutation has produced distinct phenotypes that are recognised, selected, and maintained by farmers. Most recently, Soulard et al. (2017) have mapped polymorphic SNP and SSR loci across the entire taro nuclear genome, while Yin et al. (2021) have published nearly complete sequences for all 14 chromosomes in taro.

Somatic mutation may explain some of the morphological and genetic diversity found in taro in Togo and Africa generally, but spontaneous breeding among diploid cultivars in Africa may also be involved. The chromosome numbers of Togo cultivars have not been studied, but triploid taros are widespread and common in Africa (Chaïr et al., 2016) and the neighbouring country of Burkina Faso (Traore, 2013), and can be assumed to be inherently sterile because they are triploids. The eddoe-type taros (C. esculenta var. antiquorum) in Togo are likely to be triploids, as this morphotype is generally triploid in neighbouring Burkina Faso (Traore, 2013) and eastern Asia (Plucknett, 1983; Matthews, 2014; Wang et al., 2020), but this cannot be assumed - if the diploid (fertile) progenitors of triploid eddoe cultivars still exist, some might share the eddoe mor- photype. It also cannot be assumed that the dasheen types are diploid. There are multiple triploid lineages in taro, and some dasheen and intermediate morphotypes are also triploid (Kreike et al., 2004).

The results of our initial primer screening corroborate those of Traore (2013), who found that primers designed for $C$. esculenta are not transferable to Xanthosoma spp. accessions. We also found that, conversely, the primers designed for Xanthosoma do not amplify $C$. esculenta accessions. In their original report of the HK primers, Hu et al. (2009) surveyed 30 plants from several provinces of China. Chaïr et al. (2016) screened 64 primer pairs developed from $C$. esculenta and $A$. paeoniifolius, and selected 11 from C. esculenta, of which three were from the HK primer series. This study (the largest survey of SSR diversity in taro) included 321 cultivars from 19 countries in Asia, Africa, America and the Pacific. Several HK primers were also used by Hunt et al. (2013). Including the present Togo survey, results for HK7, HK22 and HK26 can now be compared across four studies (Table 5). The largest number of alleles was found in the largest sample set representing many countries (Chaïr et al., 2016), which is not surprising. The surprise here is that Togo, a relatively small country far from Asia, displayed only slightly fewer alleles than a similar number of plants from across China (Hu et al., 2009), a much larger country that is also a candidate region for the origin of triploid taros (Matthews, 2014; Wang et al., 2020; Zhu et al., 2000). The number of alleles in two wild breeding populations in Papua New Guinea and an adjacent region of northern Australia was larger than in the China and Togo cultivars, but also much less than in the large survey by Chaïr et al. (2016).

The relatively low number of alleles detected in Togo presumably reflects the small number of plants

Table 5 - Sample size ( $\mathrm{n}$ ) and number of alleles at SSR loci in Taro, in four different studies using the HK primer series designed by Hu et al. (2009)

\begin{tabular}{|c|c|c|c|c|}
\hline \multirow[b]{2}{*}{ Locus } & \multicolumn{4}{|c|}{ Number of alleles } \\
\hline & $\begin{array}{c}\text { Hu et al. (2009), } \\
n=30, \text { China }\end{array}$ & $\begin{array}{c}\text { Hunt et al. (2013), n=42-49, } \\
\text { Australia \& PNG } \\
\text { (two wild populations) }\end{array}$ & $\begin{array}{c}\text { Chaïr et al. (2016), } \\
n=321 \\
\text { (19 countries excl. China) }\end{array}$ & $\begin{array}{c}\text { Present study } \\
n=26 \text {, Togo }\end{array}$ \\
\hline HK5 & 6 & 10 & - & 3 \\
\hline HK7 & 4 & 2 & 12 & 4 \\
\hline HK22 & 3 & - & 18 & 3 \\
\hline HK26 & 5 & 8 & 28 & 3 \\
\hline HK31 & 3 & 4 & - & 2 \\
\hline HK34 & 3 & 9 & - & 3 \\
\hline HK35 & 3 & 11 & - & 4 \\
\hline
\end{tabular}

$(-)=$ loci not studied 
tested, and the relatively low genetic diversity of taro in Africa generally (Chaïr et al. 2016). Nevertheless, the overall diversity of taro in Togo, and in the neighbouring countries of Ghana and Burkina Faso (Traore, 2013) does suggest a complex history of the crop in the region, and in Africa.

Among published studies of SSR diversity in taro (Table S1), no two studies have used the same methods to collect, maintain and test plants, and no standard set of primer pairs and target loci has emerged. Crucially, different sample sets differ in whether they represent initial collections created to assess diversity in possibly-identical cultivars from different locations (as in the present study), or later-stage collections in which apparent duplicates have been removed. Observed diversity depends on how plants are collected, how many are collected, and how each collection is maintained over time. Taro and new cocoyam collections are constructed "populations" of clones, not random samples from freely breeding populations. For all of these reasons, we do not compare our statistical estimates (calculated data) with those of other small-scale studies. In the near future, new techniques for large-scale and low-cost DNA sequencing may allow more accurate, comprehensive and direct comparison of genotypes in different cultivar assemblages. Already for taro, public databases contain records of thousands of SSR and SNP (single nucleotide polymorphism) loci revealed by whole-genome and transcriptome studies (Liu et al., 2015; You et al., 2015; Helmkampf et al., 2017; Soulard et al., 2017; Wang et al., 2020), and a draft sequence for all 14 chromosomes has been published (Yin et al., 2021).

In the Togo collection, flowering occurred among accessions of both species, but fruiting and seed production were not observed. Togo has a tropical savannah climate, with distinct wet and dry seasons, and annual rainfall ranging from around $800 \mathrm{~mm}$ to 1,600 mm (Djaman et al., 2017). In Burkina Faso, in the same general climate zone, but further Northwest, most taro is mostly grown in provinces with annual rainfall ranging from around $700 \mathrm{~mm}$ to 1,100 mm, near Togo (Traore, 2013). Although conditions during the wet season in Togo (April to October) might be suitable for breeding by taro, dry and windy conditions during the winter harmattan (Ern, 1979) would be fatal for unprotected seedlings. These are very different circumstances from those in the natural range of taro, in the tropical rainforest zone of Asia and the western Pacific, where wild breeding populations are found (Matthews, 1991; Hunt et al., 2013; Matthews, 2014). Togo itself lies in a dry savannah corridor (the Dahomey Gap) flanked by tropical rainforest (the Upper and Lower Guinean Forests) where spontaneous breeding by taro may be possible. Breeding and selection of taro cultivars in these nearby forest regions might have contributed to some of the diversity found in Togo.

Different strategies are suggested here for future development of taro and new cocoyam in Togo. For taro, it will be rewarding to study the existing range of eddoe and dasheen cultivars further, and to make experimental introductions of new cultivars from outside Africa, following the example of Ouedraogo et al. (2018). Efforts will be needed to produce disease-free stocks of existing cultivars so that fair comparisons can be made with newly-introduced plants that are disease free. New cocoyam, a relatively modern historical introduction, has spread widely in Africa, and a lack of diversity is clear among the accessions collected in Togo. International collaboration is needed to identify and introduce new cultivars for evaluation under local conditions. This will be difficult, as there are no international breeding programmes for the crop, and little is known about the origins and diversity of cultivated Xanthosoma species in Central and South America. Xanthosoma spp. are even more neglected as orphan crops than taro (Matthews and Ghanem, 2021).

Together, taro and new cocoyam offer a range of cultivars suitable for cultivation in wetland to dryland environments. Agriculture in Togo is predominantly rainfed and often experiences both flooding and drought (Djaman et al., 2017). In seasons and locations when water is abundant, the flooding tolerance of dasheen taro (Onwueme, 1999) is a positive attribute that can enhance the food security of farmers working in riverine flood plains. When irrigation is provided, very good yields of taro can be expected in otherwise dry environments: this is shown by the success of taro as an irrigated summer crop in the eastern Mediterranean (Matthews, 2006), a region with long dry summers and relatively little annual rainfall (approx. $400 \mathrm{~mm}$ per year in the main agricultural districts of Cyprus). Over the last 50 years, climate change has been very obvious throughout Togo, with the wet season becoming 1-2 months shorter (Djaman et al., 2017; Gadédjisso-Tossou, 2018). During the period 1961-2001, for example, annual precipitation decreased at $80 \%$ of weather stations across the country (Djaman et al., 2017). 
Under these circumstances, maintaining or expanding the cultivation of taro and new cocoyam may come to depend on the success or otherwise of efforts to improve methods for water storage, conservation and irrigation in Togo.

\section{Acknowledgements}

The authors greatly appreciate the International Foundation for Science (IFS Research Grant No. C/5866-2, 2020-2023) for providing research funds. The contribution by Matthews was partly funded by JSPS Kakenhi No. 17H04614 (2017-2020). Thanks also to E. Tabuchi, Osaka, for assistance with figures and tables.

\section{References}

AHMED I., LOCKHART P.J., AGOO E.M.G., NAING K.W., NGUYEN D.V., MEDHI D.K., MATTHEWS P.J., 2020 Evolutionary origins of taro (Colocasia esculenta) in Southeast Asia. - Ecology and Evolution, 10: 1353013543.

BAMMITE D., 2018 - Assessment of agromorphological and molecular diversity of Colocasia esculenta (L.) Schott and Xanthosoma mafaffa (L.) Schott in Togo. - PhD Thesis. University of Lomé, Togo, pp. 162.

BAMMITE D., MATTHEWS P.J., DAGNON D.Y., AGBOGAN A., ODAH K., DANSI A., TOZO K., 2018 a - Constraints to production and preferred traits for taro (Colocasia esculenta) and new cocoyam (Xanthosoma mafaffa) in Togo, West Africa. - African Journal of Food, Agriculture, Nutrition and Development, 18: 1338813405.

BAMMITE D., MATTHEWS P.J., DAGNON D.Y., AGBOGAN A., ODAH K., DANSI A., TOZO K., 2018 b - Agro morphological characterization of taro (Colocasia esculenta) and yautia (Xanthosoma mafaffa) in Togo, West Africa. - African Journal of Agricultural Research, 13: 934-945.

BOWN D., 2000 - Aroids: Plants of the Arum family. Second edition. - Timber Press, Portland, USA, pp. 392.

CASTRO G.R., 2006 - Studies on cocoyam (Xanthosoma spp.) in Nicaragua, with emphasis on Dasheen mosaic virus. - Doctoral thesis. Swedish University of Agricultural Sciences, Uppsula, Sweden.

CATHEBRAS C., TRAORE R., MALAPA R., RISTERUCCI A.M., CHAïR H., 2014 - Characterization of microsatellites in Xanthosoma sagittifolium (Araceae) and cross-amplification in related species. - Applications in Plant Sciences, 2: 1-5.

CHAÏR H., TRAORE R.E., DUVAL M.F., RIVALLAN R., MUKHERJEE A., ABOAGYE L.M., RENSBURG W.J.,
ANDRIANAVALONA V.V., DE CARVALHO M. A.A.P., SABORIO F., PRANA M.S., KOMOLONG B., LAWAC F., LEBOT V., 2016 - Genetic diversification and dispersal of Taro (Colocasia esculenta (L.) Schott). - PLoS ONE, 11: 1-19.

COATES D.J., YEN D.E., GAFFEY P.M., 1988 - Chromosome variatin in taro, Colocasia esculenta: implications for origin in the Pacific.- Cytologia, 53(3): 551-560.

COURSEY D.G., 1984 - Potential utilization of major root crops, with special emphasis on human, animal, and industrial uses, pp. 25-35. - In: TERRY E.R., E.V. DOKU, O.B. ARENE, and N.M. MAHUNGU (eds.) Tropical root crops: Production and uses in Africa. International Society for Tropical Root Crops, Douala, Cameroon, pp. 232.

CROAT T.B., DELANNAY X., 2017 - A revision of Xanthosoma (Araceae). Part 3: Guianas. - Aroideana, 40: 582-649.

CUSIMANO N., SOUSA A., RENNER S.S., 2012 - Maximum likelihood inference implies a high, not a low, ancestral haploid chromosome number in Araceae, with a critique of the bias introduced by ' $x$ '. - Ann. Bot., 109(4): 681-692.

DEVI A.A., 2012 - Genetic diversity analysis in taro using molecular markers - an overview. - J. Root Crops, 38(1): 15-25.

DJAMAN K., SHARMA V., RUDNICK D.R., KOUDAHE K., IRMAK S., AMOUZOU K.A., SOGBEDJI J.M., 2017 Spatial and temporal variation in precipitation in Togo. - Int. J. Hydro., 1(4): 97-105.

DOUNGOUS O., KALENDAR R., ADIOBO A., SCHULMAN A. H., 2015 - Retrotransposon molecular markers resolve cocoyam (Xanthosoma sagittifolium) and taro (Colocasia esculenta) by type and variety. Euphytica, 206: 541-554.

ERN H., 1979 - Die Vegetation Togos. Gliederung, Gefährdung, Erhaltung. - Willdenowia, 1: 295-312.

FULLER D.Q., BOIVIN N., HOOGERVORST T., ALLABY R., 2011 - Across the Indian Ocean: the prehistoric movement of plants and animals. - Antiquity, 85: 544-558.

GADÉDJISSO-TOSSOU A., AVELLÁN T., SCHÜTZE N., 2018 Potential of deficit and supplemental irrigation under climate variability in Northern Togo, West Africa. Water, 10: 1803.

GIACOMETTI D.C., LEON J., 1994 - Tannia, yautia (Xanthosoma sagittifolium). - In: HERNANDO BERMEJO J.E., and J. LEON (eds.) Neglected crops: 1492 from a different perspective. FAO Plant Production and Protection Service, Rome, Italy.

GONÇALVES E.G., 2011 - The commonly cultivated species of Xanthosoma Schott (Araceae), including four new species. - Aroideana, 34: 3-23.

GRIMALDI I.M., 2016 - Taro across the oceans, journeys of one of our oldest crops, pp. 67-81. - In: THANHEISER U. (ed) News From the Past, Progress in African Archaeobotany. Proceedings of the 7th International 
Workshop on African Archaeobotany in Vienna, 2-5 July 2012, Barkhuis, Groningen, The Netherlands, pp. 136.

HELMKAMPF M., WOLFGRUBER T.K., BELLINGER M.R., PAUDEL R., KANTAR M.B., MIYASAKA S.C., KIMBALL H.L., BROWN A., VEILLET A., READ A., SHINTAKU M., 2017 - Phylogenetic relationships, breeding implications, and cultivation history of Hawaiian taro (Colocasia esculenta) through genome-wide SNP genotyping. - J. Hered., 109(3): 272-282.

HU K., HUANG X.F., KE D., DING Y.I., 2009 Characterization of 11 new microsatellite loci in taro (Colocasia esculenta). - Mol. Ecol. Resour., 9: 582-584.

HUNT H.V., MOOTS H.M., MATTHEWS P.J., 2013 - Genetic data confirms field evidence for natural breeding in a wild taro population (Colocasia esculenta) in northern Queensland, Australia. - Genet. Resour. Crop Evol., 60: 1695-1707.

IBPGR, 1989 - Descriptors for Xanthosoma. - International Board for Plant Genetic Resources (IBPGR), Rome, Italy.

IITA BIOSCIENCE CENTER, 2017 - Optimized SDS protocol for samples with high phenolic content (yam, kola, okra). - Biosciences Center, International Institute of Tropical Agriculture (IITA), Ibadan, (Nigeria).

IPGRI, 1999 - IPGRI Descriptors for Taro (Colocasia esculenta). - International Plant Genetic Resources Institute (IPGRI), Rome, Italy.

KARIKARI S.K., 1971 - Cocoyam cultivation in Ghana. World Crops., 23(3): 118-122.

KARIKARI S.K., 1979 - Preliminary evaluation of 14 Puerto Rican and six Ghanaian varieties of cocoyam (Colocasia and Xanthosoma spp.) under Ghanaian conditions, pp. 615-627. - In: BELEN E.H., and M. VILLANUEVA (eds.) Proceedings of the 5th International Symposium on Tropical Root and Tuber Crops, 17-21 Sept., Philippine Council for Agriculture and Resources Research, Laguna (Philippines).

KREIKE C.M., VAN ECK H.J., LEBOT V., 2004 - Genetic diversity of taro, Colocasia esculenta (L.) Schott, in Southeast Asia and the Pacific. - Theor. Appl. Genet., 109(4): 761768.

LAKHANPAUL S., VELAYUDHAN K.C., BHAT K.V., 2003 Analysis of genetic diversity in Indian taro (Colocasia esculenta (L.) Schott) using random amplified polymorphic DNA (RAPD) markers. - Genet. Resour. Crop Evol., 50: 603-609.

LIU H., YOU Y., ZHENG, X., DIAO Y., HUANG X., HU Z., 2015 - Deep sequencing of the Colocasia esculenta transcriptome revealed candidate genes for major metabolic pathways of starch synthesis. - S. Afr. J. Bot., 97: 101106.

MASUNO T., NGUYEN L.D., NGUYEN V.D., MATTHEWS P.J., 2012 - Fodder sources and backyard pig husbandry in BaVi, Hanoi province, northern Vietnam, in Anon. Proc. of the 1st International Conference on Animal Nutrition and Environment, Khon Kaen University
Press, Khon Kaen, Thailandia, pp. 657-660.

MATTHEWS P.J., 1991 - A possible tropical wildtype taro: Colocasia esculenta var. aquatilis. - Bull. Indo-Pacific Prehistory Assoc., 11: 69-81.

MATTHEWS P.J., 2006 - Written records of Taro in the Eastern Mediterranean, pp. 419-426. - In: FUSUN ERTUG Z. (ed.) Proceedings of the Fourth International Congress of Ethnobotany (ICEB 2005), Istanbul-Turkey, 21-26 August 2005, Yayinlari, Istanbul, Turkey.

MATTHEWS P.J., 2010 - An introduction to the history of taro as a food, pp. 6-28. - In: RAO V.R., P.J. MATTHEWS, P.B. EYZAGUIRRE, and D. HUNTER (eds.) The global diversity of Taro: Ethnobotany and conservation. Bioversity International, Rome, Italy, pp. 202.

MATTHEWS P.J., 2014 - On the trail of Taro: An exploration of natural and cultural history. Senri Ethnological Studies 88. - National Museum of Ethnology, Osaka, Japan, pp. 429.

MATTHEWS P.J., GHANEM M.E., 2021 - Perception gaps that may explain the status of taro (Colocasia esculenta) as an "orphan crop". - Plants People Planet, 3: 99112.

MWENYE O., LABUSCHAGNE M.T., HERSELMAN L., BENESI I.R.M., CHIPUNGU F.P., 2010 - Ethno-botanical and morphological characterisation of cocoyams (Colocasia esculenta $L$. Schott and Xanthosoma sagittifolum $L$. Schott) germplasm in Malawi. - Second RUFORUM Biennial Meeding Entebbe, Uganda, 20-24 September, pp. 193-199.

NEI M., 1973 - Analysis of gene diversity in subdivided populations. - Proc Nat Acad Sci., 70(12): 3321-3323.

NEI M., TAJIMA F., TATENO Y., 1983 - Accuracy of estimated phylogenetic trees from molecular data. - J. Mol. Evol., 19(2): 153-170.

OKEREKE N.R., 2020 - Cocoyam genomics: present status and future perspectives. - Nigerian Agricultural Journal, 51: 207-212.

ONOKPISE O.U., BOYA-MEBOKA M., WUTOH J.T., 1992 Hybridization and fruit formation in macabo cocoyam (Xanthosoma sagittifolium (L) Schott). - An. Appl. Biol., 120: 527-535.

ONWUEME I., 1999 - Taro cultivation in Asia and the Pacific. - FAO, Regional Office for Asia and the Pacific, Bangkok, Thailandia.

ONYEKA J., 2014 - Status of Cocoyam (Colocasia esculenta and Xanthosoma spp) in West and Central Africa: Production, household importance and the threat from leaf blight. - CGIAR Research Program on Roots, Tubers and Bananas (RTB), Lima, Peru.

OUEDRAOGO N., TRAORE R.E., BATIONO/KANDO P., SAWADOGO M., ZONGO J.-D., 2018 - Agro-morphological diversity of exotic taro varieties (Colocasia esculenta L. Schott) introduced in Burkina Faso. - J. Exper. Biol. and Agric. Sci., 6: 370-385.

PEAKALL R., SMOUSE P.E., 2006 - GENALEX 6: genetic analysis in Excel. Population genetic software for teaching 
and research. - Mol. Ecol. Resour., 6(1): 288-295.

PINSTRUP-ANDERSEN P., PANDYA-LORCH R., ROSEGRANT M.W., 1999 - World food prospects: Critical issues for the early twenty-first century. - Proc. Int. Food Policy Resour. Institute, Washington D.C., USA, pp. 30.

PLOWMAN T., 1969 - Folk uses of New World aroids. Economic Bot., 23: 97-122.

PLUCKNETT D.L., 1983 - Taxonomy of the genus Colocasi, pp. 14-33. - In: WANG J.-K. (ed.) Taro: A review of Colocasia esculenta and its potentials. University of Hawaii Press, Honolulu, Hawaii, pp. 400.

QUERO-GARCIA J., IVANCIC A., LEBOT V., 2010 - Taro and Cocoyam, pp. 149-172. - In: BRADSHAW J.E. (ed.) Root and tuber crops. Springer New York, Dordrecht and London, pp. 298.

RIBEIRO PEREIRA P., BERTOZI DE AQUINO MATTOS É., NITZSCHE TEIXEIRA FERNANDES CORRÊA A.C., AFONSO VERICIMO M., MARGARET FLOSI PASCOALIN V., 2021 Anticancer and immunomodulatory benefits of taro (Colocasia esculenta) corms, an underexploited tuber crop. - Int. J. Mol. Sci., 22: 1-32.

SANTOSA E., LIAN C.L., PISOOKSANTIVATANA Y., SUGIYAMA N., 2007 - Isolation and characterization of polymorphic microsatellite markers in Amorphophallus paeoniifolius (Dennst.) Nicolson, Araceae. - Mol. Ecol. Resour., 7(5): 814-817.

SINGH D., JACKSON G., HUNTER D., FULLERTON R., LEBOT V., TAYLOR M., IOSEFA T., OKPUL T., TYSON J., 2012 Taro leaf blight - a threat to food security. - Agric., 2: 182-203.

SOULARD L., MOURNET P., GUITTON B., CHAÏR H., 2017 Construction of two genetic linkage maps of taro using single nucleotide polymorphism and microsatellite markers. - Molecular Breeding, 37: e37.
TRAORE R.E., 2013 - Etude de la diversité du taro (Colocasia esculenta (L.) Schott): cas d'une collection du Burkina Faso et d'une collection internationale. - Ph.D. Thesis, Université de Ouagadougou, Burkina Faso, pp. 182.

VANDENBROUKE H., MOURNET P., VIGNES H., CHAÏR H., MALAPA R., DUVAL M.F., LEBO, V., 2016 - Somaclonal variants of taro (Colocasia esculenta Schott) and yam (Dioscorea alata L.) are incorporated into farmer' portfolios in Vanuatu. - Genet. Resour. Crop Evol., 63: 495511.

WADA E., ASFAW Z., FEYISSA T., TESFAYE K., 2017 Farmers' perception of agromorphological traits and uses of cocoyam (Xanthosoma sagittifolium (L.) Schott) grown in Ethiopia. - AJAR, 12(35): 2681-2691.

WADA E., FEYISSA T., TESFAYE K., MÜLLER C.M., GEMEINHOLZER B., 2018 - Genetic diversity of Ethiopian Xanthosoma sagittifolium (L.) Schott accessions assessed with AFLPs. - Genet Resour Crop Evol., 65(8): 2095-2105.

WANG Z., SUN Y., HUANG X., LI F., LIU Y., ZHU H., LIU Z., KE W., 2020 - Genetic diversity and population structure of eddoe taro in China using genome-wide SNP markers. Peer J., 8: e10485.

YIN J., JIANG L., WANG L., HAN X., GUO W., LI C., ZHOU Y., DENTON M., ZHANG P., 2021 - A high-quality genome of taro (Colocasia esculenta (L.) Schott), one of the world's oldest crops. - Mol. Ecol. Resour., 21: 68-77.

YOU Y., LIU D., LIU H., ZHENG X., DIAO Y., HUANG X. HU Z., 2015 - Development and characterisation of EST-SSR markers by transcriptome sequencing in taro (Colocasia esculenta (L.) Schoot). - Mol. Breeding, 35: e134.

ZHU D., EYZAGUIRRE P.B., ZHOU M., SEARS L., LIU G., 2000 - Ethnobotany and genetic diversity of Asian taro: focus on China. - IPGRI Office for East Asia, Beijing, RPC. 
